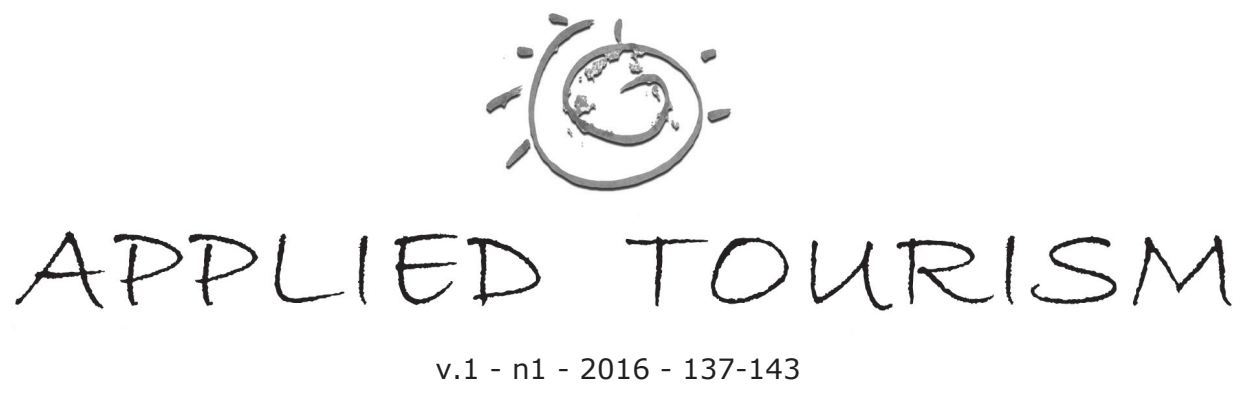

\title{
PROPOSTA DE MENSURAÇÃO DA QUALIDADE DOS SERVIÇOS DA HOTELARIA NO CHUÍ, RS, BRASIL
}

\section{PROPOSAL FOR MEASURING THE QUALITY OF HOTEL SERVICES IN CHUÍ, RS, BRAZIL}

\author{
Silvia Cecilia Pino Silvera - Bacharel em Turismo Binacional - Universidade Federal do Rio \\ Grande (FURG). E-mail: ceciliasilvera1992@hotmail.es \\ Melise de Lima Pereira - Doutoranda em Turismo e Hotelaria - Universidade do Vale do Itajaí \\ (UNIVALI). E-mail: melisepereira@furg.br
}

Recebido/Received: 10 setembro/september 2014. Aprovação/Approval: 18 janeiro/january 2015.

\begin{abstract}
Resumo: O presente trabalho é uma proposta de avaliação da qualidade dos serviços hoteleiros na cidade do Chuí, RS, Brasil. O objetivo geral é mensurar a qualidade dos serviços da hotelaria na cidade do Chuí, buscando analisar as diferenças existentes (lacunas), através da aplicação do modelo SERVQUAL, entre o que os clientes pretendem e o que eles recebem ao consumir tais serviços. Em termos metodológicos a pesquisa caracteriza-se por ser exploratória e descritiva. O item menos avaliado foi o item segurança, e o melhor avaliado ficou com o item confiabilidade. Notou-se que em nenhuma das dimensões os clientes alcançaram suas expectativas de satisfação, demonstrando o nível de exigência desses consumidores e os pontos em que a empresa deve ter mais atenção.Desta maneira, fica demonstrado que os hotéis devem realizar estas pesquisas habitualmente junto aos
\end{abstract}

Abstract: This work is a proposal for evaluating the quality of hotel services in the city of Chuí, in the Brazilian state of Rio Grande do Sul. The general objective is to measure quality in hotel services in the city, seeking to analyze, through the application of the SERVQUAL model, the differences (gaps) between customers' expectations and perceptions of these services. In methodological terms, the research is characterized as exploratory and descriptive. The item that received the lowest score was Assurance, while the item with the best score was Reliability. It was noted that none of the dimensions meet their customers' expectations, thus showing their high standards and the points on which the company needs to pay more attention. It was therefore demonstrated that the hotels should carry out these surveys with their customers on a regular basis, as they can be of great assistance in achieving the ideal service. 
clientes, pois eles têm muito a colaborar para alcançar a qualidade ideal do serviço.

Palavras-chave: Marketing; Hospedagem; Qualidade dos serviços.

\section{INTRODUÇÃO}

Para toda empresa é importante gerar valor e satisfação para os seus clientes para sobreviver no mercado atual. No setor da hospedagem isto não e diferente, já que os hotéis representam um suporte à atividade turística.

Sendo assim, o objetivo geral é mensurar a qualidade dos serviços da hotelaria na cidade do Chuí, RS, Brasil, buscando analisar as diferenças existentes (lacunas), através da aplicação do modelo SERVQUAL, entre o que os clientes pretendem e o que eles recebem ao consumir tais serviços.

Portanto, a realização deste trabalho justifica-se em demonstrar a importância da realização destas pesquisas e de se obter conhecimento sobre a expectativa do consumidor e seu grau de satisfação antes e pós- estadia nos hotéis da cidade do Chuí.

Para a realização desta etapa de teste de avaliação dos serviços, o objeto de estudo é um determinado hotel da cidade. O trabalho realizou-se em duas etapas, a primeira de revisão bibliográfica de artigos científicos na área de marketing e qualidade dos serviços a fim de embasar e contextualizar o problema de pesquisa. Na segunda etapa, referente à aplicação da pesquisa, utilizou-se o instrumento de questionário SERVQUAL e posterior análise dos dados coletados.

\section{FUNDAMENTAÇÃO TEÓRICA}

\section{Marketing e qualidade dos serviços}

Morrison (2012) ao definir marketing enfatiza a importância de atender as necessidades dos clientes. Castelli (2003) também salienta que a função do marketing é ser uma espécie de radar, que deve captar necessidades, desejos e expectativas dos clientes. Observa-se nos dois autores a forte presença da importância de se ter o foco no cliente para o sucesso de um serviço. No turismo, a hospedagem é uma necessidade dos turistas, uma demanda a ser satisfeita,
Keywords: marketing, accommodation, quality of services.

\section{INTRODUCTION}

It is important for any company to generate value and satisfaction for its clients, in order to survive in today's market. In the accommodation sector things are no different, as hotels represent a support for tourism.

The general objective is to measure the quality of hotel services in the city of Chuí, RS, Brazil, seeking to analyze the differences (gaps) that exist between what clients want, and what they actually receive when consuming these services, through the application of the SERVQUAL model.

This work is justified by the fact that it demonstrates the importance of carrying out these surveys, and of obtaining knowledge of consumer's expectations and their degree of satisfaction, before and after staying at the hotels in the city of Chuí.

For this stage of the service evaluation test, the object of study was a hotel in the city. The work was carried out in two stages; the first was a literature review of scientific articles in the areas of marketing and quality of services, to act as the basis and context for the research problem. The second stage was the application of the survey, using the SERVQUAL questionnaire, with subsequent analysis of the data collected.

\section{THEORETICAL FRAMEWORK}

\section{Marketing and quality of services}

Morrison (2012) defines marketing emphasizing the importance of meeting customers' needs. Castelli (2003) also highlights that the function of marketing is to act as a kind of 'radar', picking up on customers' needs, desires and expectations. Both authors point out the importance of focusing on the customer in order to be successful. In tourism, accommodation is a tourist need, a demand to be met, and it is distinct in nature from other sectors. According to Cooper et al. (2007, p. 394), "the majority of products in the hotel and accommodation industry are a combination of tangible objects and performances, or intangible experiences." 
e possui uma natureza distinta comparada com outros setores. Segundo Cooper et.al. (2007, p.394) "a maior parte dos produtos de hotelaria e hospedagem são uma combinação de objetos tangíveis e desempenhos ou experiências intangíveis."

Para a realização do gerenciamento da qualidade dos serviços de hospedagem deve se prestar atenção nas características especificas do serviço e investir, segundo Castelli (2003, p.34), em três pontos essenciais "o hardware (equipamentos), o software (procedimentos) e o humanware (elemento humano)".

Segundo Cooper et al. (2007, p.563) a "qualidade é, [...] um dos componentes fundamentais a contribuir para uma estratégia de sucesso, e se tornou um componente competitivo central na estratégia de serviços de uma organização".

Parasuraman, Zeithaml e Berry (1985) apud Cooper et.al. (2007) desenvolveram um modelo de qualidade de serviços que afirma que o consumidor avalia a qualidade de uma experiência de serviços na diferença do serviço esperado frente ao percebido. O modelo apresenta os principais pontos para se prestar um serviço de acordo a qualidade esperada pelo consumidor, divididos em cinco lacunas. Neste trabalho será utilizado a lacuna cinco como forma de análise, referente à diferença entre serviço esperado e serviço percebido.

METODOLOGIA

Em termos metodológicos a pesquisa caracteriza-se por ser exploratória e descritiva. O trabalho, proposta inicial de mensuração, dividiu-se em duas etapas, a primeira constou de uma revisão bibliográfica para embasamento do resumo expandido. A segunda etapa caracterizou-se pela utilização do modelo de questionário SERVQUAL proposto por Parasuraman et. al. (1988) aplicado em duas etapas: a primeira referente à expectativa, sendo esta etapa aplicada durante o check in dos hóspedes e a segunda, referente ao desempenho avaliado, sendo esta etapa aplicada no check out em um hotel determinado do Chuí, RS, Brasil.

Tal modelo baseia-se em que o cliente antes do consumo de um determinado serviço tem certas expectativas através de uma série de necessidades pessoais, fatores e dimensões externas, o que lhe permite avaliar o desempenho depois de realizar o consumo.
To carry out quality management of accommodation services, it is necessary to pay attention to the specific characteristics of the service, and to invest, according to Castelli (2003, p. 34), in three essential points: the hardware (equipment), the software (procedures) and the humanware (human element)".

According to Cooper et al. (2007, p. $563)$, "quality is [...] one of the fundamental components to a strategy of success, and has become a key competitive component in the service strategy of an organization".

Parasuraman, Zeithaml and Berry (1985) (as cited in Cooper et al., 2007) developed a model of quality service in which the consumer evaluates the quality of a service experience by analyzing the difference between the expectation of the service, and the actual perception. The model presents the main points for providing a service according to the quality expected by the consumer, divided into five gaps. This work draws in the fifth gap as a frame for the analysis, referring to the difference between the expected service and the perceived service.

\section{METHODOLOGY}

In methodological terms, the research is of an exploratory and descriptive nature. The initial measuring proposal is divided into two stages; the first consisted of a literature review to form the basis of the expanded abstract. The second stage was characterized by the use of the SERVQUAL questionnaire model, proposed by Parasuraman et al. (1988) applied in two stages: the first relates to expectation, and is applied during the check-in of guests; and the second, regarding performance evaluation, is applied on checkout from a hotel in Chuí, RS, Brazil.

This model is based on the view that the customer, before consuming a particular service, has certain expectations, due to a series of personal needs and external factors and dimensions, which enables him or her to evaluate the performance after the act of consumption.

The model developed by Parasuraman et al. (1988) evaluates five dimensions that cover reliability, assurance, tangibles, empathy and responsiveness. These dimensions are divided into twenty-two (22) questions. Using the model, it is possible to find out 
O modelo desenvolvido por Parasuraman et. al. (1988) avalia cinco dimensões que abarcam aspectos tangíveis, confiabilidade, presteza, segurança e empatia. Essas dimensões apresentam-se divididas em vinte e duas (22) questões. Através do modelo é possível conhecer o que os consumidores esperam e qual foi o serviço recebido. As lacunas de insatisfação são uma maneira organizada de avaliar os defeitos na qualidade do serviço prestado. A escala de avaliação utilizada foi do tipo likert, de 1 a 7 pontos, onde um (1) significa que discorda fortemente e sete (7) que concorda fortemente. A vantagem desta escala é que permite conhecer o nível de importância percebido de maneira mais concreta, já que apresenta pontos intermediários.

Ao todo foram aplicados dez questionários, entre os dias 1 e 3 de outubro de 2013. Dos questionários aplicados seis foram validados por terem sido realizados nas duas etapas, quatro dos dez aplicados foram invalidados por não terem completado a segunda etapa.

\section{ANÁLISE DOS RESULTADOS}

Após o cruzamento dos dados pode ser observado na Tabela 1 , a seguir, os valores médios para a expectativa e o desempenho. Nota-se que em nenhuma das dimensões os clientes alcançaram suas expectativas de satisfação, demonstrando o nível de exigência desses consumidores e os pontos em que a empresa deve ter mais atenção.

$O$ item menos avaliado foi o item segurança, e o melhor avaliado ficou com o item confiabilidade, mas de modo geral nenhum item alcançou o desempenho ideal que seria o equilíbrio ou superação das expectativas. Isto quer dizer que a empresa deve ter maior atenção nos aspectos segurança e presteza. Por outro lado, quanto à confiabilidade, empatia e aspectos tangíveis a lacuna existente é menor (Tabela 1: Média da expectativa e do desempenho por dimensões. Fonte: pesquisa direta, outubro, 2013).

Do total dos respondentes $16,6 \%$ foram mulheres, as quais tiveram uma média de expectativa dos serviços de 4,50 pontos numa escala de 7 pontos, e um desempenho de 4,13 pontos na mesma escala; resultando numa lacuna de 0,37. Já os homens tiveram uma média de expectativa de 5,11; e um desempenho de 4,33, como resultado uma lacuna de 0.78. Assim demonstra-se que what consumers want and, what service was received. Dissatisfaction gaps are a systematic procedure to assess the quality of the service provided. The assessment scale used was a 5-point Likert scale, from 1 to 7 points, where one (1) means strongly disagree and seven (7) strongly agree. The advantage of this scale is that it enables us to find out the level of perceived importance more concretely, as it has intermediate points.

A total of ten questionnaires were applied, between October 1st and 3rd 2013. Of the questionnaires applied, six were validated as they were carried out in two stages; four were invalidated because they did not complete the second stage.

\section{ANALYSIS OF THE RESULTS}

After cross-referencing the data, Table 1 , below, shows the mean values for expectation and performance. It is noted that in none of the dimensions were the customers' expectations fully met, showing the consumers' high standards, and the aspects on which the company should improve.

The item given the lowest score was Assurance, while the highest score was given to the item Reliability. In general, none of the items got the ideal Performance score, which would be an equal or a higher value to Expectation. This means that the company should pay more attention to the aspects of Assurance and Responsiveness. On the other hand, when it comes to Reliability, Empathy and Tangibles, the gap is smaller (Table 1: Average for expectation and performance by dimensions. Source: the authors (2013).

Of the total respondents $16.6 \%$ were women, with an average Expectation of services of 4.50 points on a scale of 7 points, and a Performance of 4.13 points on the same scale, resulting in a gap of 0.37 . The men had an average Expectation of 5.11; and a Performance of 4.33 , resulting in a gap of 0.78 . This demonstrates that men were less satisfied than women with the services they received in the hotel investigated.

As regards the Tangibles, in the results obtained, the item that surpassed the customers' expectations related to the visually attractive facilities, with a gap of 0.17 of surpassed expectations. In relation to modern equipment, the hotel had a gap of 1 negative point, in which guests complained about the 
homens ficaram menos satisfeitos do que as mulheres com os serviços encontrados no hotel pesquisado.

No que se refere a aspectos tangíveis, nos resultados obtidos o item que superou a expectativa dos clientes foi o que se refere às instalações visualmente atrativas ficando com um hiato (lacuna) de 0,17 de superação. Já no que se refere a equipamentos modernos o hotel teve um hiato (lacuna) de 1 ponto negativo,em que os hóspedes reclamaram do serviço de internet.

$\mathrm{Na}$ dimensão confiabilidade, a questão sobre o cumprimento do tempo prometido para o desenvolvimento de uma atividade superou as expectativas dos hóspedes alcançando um hiato positivo de 0,16 . Quanto questionados se a empresa é confiável, os hóspedes pesquisados consideram-se satisfeitos, já que as expectativas são iguais ao desempenho mensurado. $O$ item que teve menor desempenho, nesta dimensão, foi referente à segurança e a solidariedade que o hotel apresenta frente a algum problema com o cliente.

No item segurança, a maior discordância é evidenciada quanto ao suporte aos empregados, visto que as questões de expectativa são positivas e as de desempenho são negativas. Os hóspedes avaliam que os empregados obtêm suporte adequado da empresa. Logo, o item que se refere à educação dos funcionários foi o destaque desta dimensão, já que os respondentes alcançaram suas expectativas neste ponto.

A última dimensão avaliada foi a empatia, em que os hóspedes ponderaram que a empresa preocupa-se com os clientes prestando atenção individual. Isso mostra que o desempenho da empresa, embora não esteja no nível ideal (o equilíbrio ou superação das expectativas), apresenta baixo valor de diferença entre a expectativa e o desempenho.

De maneira geral pode-se observar que os pontos fortes do hotel estão na confiabilidade, na empatia e nos aspectos tangíveis, mas mesmo assim existem alguns pontos a serem mais bem trabalhados. Desta maneira, fica demonstrado que os hotéis devem realizar estas pesquisas habitualmente junto aos clientes, pois eles têm muito a colaborar para alcançar a qualidade ideal do serviço.

\section{CONSIDERAÇÕES FINAIS}

Este estudo procurou testar um modelo de avaliação da qualidade dos serviços da
Internet service.

In the dimension Reliability, the question about the completion of activities within the specified time frame surpassed the guest's expectations, reaching a positive gap of 0.16 . Regarding the questions on whether the company is reliable, the guests surveyed considered themselves satisfied, as their expectations were matched by the performance measured. The item with the lowest performance, in this dimension, was the one relating to safety and the empathy shown by the hotel when the customer has some problem.

In the item Assurance, the greatest discrepancy is evident regarding support to employees, since the issues of expectation are positive and those of performance are negative. The guests consider that employees receive adequate support from the company. Therefore, the item relating to the staff's education of the highlight of this dimension, since the respondents' expectations were reached in this point.

The final dimension assessed was Empathy, in which the guests considered the company to be concerned with its customers, paying them individual attention. This shows that the company's performance, although not at the ideal level (equal or surpassing expectations), shows little difference between the values of Expectation and Performance.

In general, it can be observed that the strong points of the hotel are Reliability, Empathy and Tangibles, but even so, there are some points that need to be more worked out in the future. Thus, it is demonstrated that hotels should carry out these surveys more often with their customers, as they can be of a great value when it comes to achieve optimum quality of service.

\section{FINAL CONSIDERATIONS}

This study sought to test a model for the assessment of the quality of services of the hotel, in a given accommodation environment in the city of Chui (RS), Brazil, through the application of the SERVQUAL model questionnaire proposed by Parasuraman et al. (1988).

In the course of the development of this work it was noted the importance of knowing the expectations and perceptions of 
hotelaria, em um determinado meio de hospedagem, na cidade do Chuí (RS), Brasil, através da aplicação do questionário de modelo SERVQUAL proposto por Parasuraman et. al. (1988).

Como pode ser observado ao longo do desenvolvimento do trabalho, é muito importante conhecer as expectativas e percepções dos clientes demonstrando que estudos como este devem ser realizados periodicamente. Também foi observado que sempre se deve ter em vista que um serviço não deve limitar seu foco unicamente aos seus interesses organizacionais e sim deve levar em conta a opinião do consumidor, que é realmente quem vai gerar retorno para a empresa.

Este trabalho teve limitações ao ser realizado como uma proposta inicial de mensuração da qualidade dos serviços da hotelaria e por possuir uma amostra pequena de clientes. A pesquisa continua em andamento visando expandir a amostra de hóspedes e a quantidade de meios de hospedagem pesquisados, para alcançar a mensuração da oferta dos serviços de hospedagem da cidade do Chuí/RS.

\section{REFERÊNCIAS}

Castelli, G. (2003). Administração Hoteleira. 9 ed. Caxias do Sul: EDUCS.

Cooper, C. et. al. (2007). Turismo, Princípios e Praticas. 3 ed. Porto Alegre: Bookman.

Eleuterio, S., De Souza, C. (2002). Qualidade na Prestação de Serviços: Uma Avaliação com Clientes Internos. Caderno de Pesquisas em Administração. Vol. 9 (3). São Paulo.

Kotler, P., Armstrong, G. (2007). Princípios de Marketing. 12 ed. São Paulo: Pearson.

Morrison, A. (2012). Marketing de Hospitalidade e Turismo. São Paulo: Cengage Learning. customers, showing that studies such as this should be carried out on a regular basis. It was also observed that it should always be borne in mind that a service should not limit its focus solely on its organizational interests, but must take into account the consumers' opinions, as they are, ultimately, the ones who generate returns for the company.

This study has limitations because it was carried out as an initial proposal for measuring the quality of hotel services and it has a small number of customers. The research is still in progress, aiming to expand the sample of guests and the quantity of accommodation establishments researched, to achieve the measurement of the supply of accommodation services in the city of Chuí/RS.

\section{REFERENCES}

Castelli, G. (2003). Administração Hoteleira. 9 ed. Caxias do Sul: EDUCS.

Cooper, C. et. al. (2007). Turismo, Princípios e Praticas. 3 ed. Porto Alegre: Bookman.

Eleuterio, S., De Souza, C. (2002). Qualidade na Prestação de Serviços: Uma Avaliação com Clientes Internos. Caderno de Pesquisas em Administração. Vol. 9 (3). São Paulo.

Kotler, P., Armstrong, G. (2007). Princípios de Marketing. 12 ed. São Paulo: Pearson.

Learning.

Morrison, A. (2012). Marketing de Hospitalidade e Turismo. São Paulo: Cengage. 


\begin{tabular}{|l|c|c|c|}
\hline & & & Hiato \\
Item & Expectativa & Desempenho & (lacuna) \\
\hline Aspectos Tangíveis & 6,58 & 5,95 & 0,63 \\
\hline Confiabilidade & 6,73 & 6,59 & 0,14 \\
\hline Presteza & 2,75 & 1,75 & 1 \\
\hline Segurança & 6,79 & 5,43 & 1,36 \\
\hline Empatia & 2,4 & 1,86 & 0,54 \\
\hline Media Total & 5,05 & 4,32 & 0,73 \\
\hline
\end{tabular}

Tabela 1: Média da expectativa e do desempenho por dimensões. Fonte: pesquisa direta, outubro, 2013.

\begin{tabular}{|l|c|c|c|}
\hline Item & Expectation & Performance & Gap \\
\hline Tangibles & 6.58 & 5.95 & 0.63 \\
\hline Reliability & 6.73 & 6.59 & 0.14 \\
\hline Responsiveness & 2.75 & 1.75 & 1 \\
\hline Assurance & 6.79 & 5.43 & 1.36 \\
\hline Empathy & 2.4 & 1.86 & 0.54 \\
\hline Total Average & 5.05 & 4.32 & 0.73 \\
\hline
\end{tabular}

Table 1: Average for expectation and performance by dimensions. Source: the authors (2013). 